\title{
Lilliputian Foreign Policy of a Small State: The Case of the Republic of Macedonia
}

\author{
Biljana Vankovska, PhD \\ Ss. Cyril and Methodius University - Skopje, Faculty of Philosophy \\ Institute of Security, defense and peace \\ E-mail: bvankovska@gmail.com
}

\begin{abstract}
The paper focuses on the foreign policy making and choices of a small and weak state, i.e. the Republic of Macedonia. The article revolves around a set of questions defining the smallness and weakness of small states in the international relations. Then it proceeds to analyze foreign policy choices and decisions of the Macedonian state since 1991. The basic hypothesis is that not only smallness is important but also the weakness of a state. Quasi-protectorates in the post-Yugoslav region can hardly afford any independent foreign policy goals and means. The link between the internal (in)stability and external interventions (international statebuilding) determines an overwhelming dependency syndrome, which predestines the affiliation of these states to the West. The rhetoric of the advancement of the New East (newly empowered Russia and China) serve only as a factor of fear that strengthens the grip of the Western alliances and organizations.
\end{abstract}

Key words: foreign policy, domestic policy, small states, international statebuilding, the Republic of Macedonia 


\section{Seccurity}

\section{Introduction: Small States in the Multipolar Global Context}

The conventional wisdom in international relations reads: the size (of a state) matters a lot. Behavior of states is determined by their military capabilities, economic power, size of territory and population, natural resources, etc. Up to recently small states have been seen as negligible in the larger context of great power politics. The only exception of this rule used to be the conglomerate of small states under the umbrella of Non-Alignment Movement during the Cold war period: they did not have power comparable to that of the West and the East but still managed to make influence within the United Nations.

It is believed that the fundamental changes of international system since the end of the Cold war have had strong implications for small state foreign policy (Hey 2003, p. 1). Unlike in the past, they have earned more visibility and even more abilities to take the advantage of their membership in various international organizations (such as EU, NATO, etc.). With no military blocks and rival superpowers to misuse them as pawns in a global competitions, they are supposed to benefit from the new international constellation. Indeed in recent years there have been a number of small states taking on an increasingly active role on the global stage. In these regard, there are two different opinions: some authors believe that changes in the international system have given present day Lilliputians new avenues to try to influence others and take on a foreign policy profile above their diminutive stature. According to this opinion, allegedly, they have a choice to pursue a foreign policy beyond what previous international constellations limit them to. The increased role of international organizations in the international system is seen as a crucial factor for this new role of small states. However, there are substantial variations among small states' foreign policy, which in some cases may be even outsized. The advocates of the other standpoint argue that behind the declaratory changes of power in the international system, the reality check shows that small states have fewer policy options now than at the height of the Cold War. For instance, the poor ones are being caught between the economic powers and institutions and their economic/fiscal demands and structural reforms on one hand, and the socio-economic expectations of their own citizens, on the other. Many of them have set the integration with Western structures as the most important strategic foreign policy goals - hanging to a pipe-dream that it would bring them social welfare and security. The wealthier ones, which are already well-integrated in the Western 


\section{Seccurity}

associations, also feel sandwiched due to the expansion of power of these integrations and try to find way to keep their relative influence from within.

The starting point of any analysis of small state foreign policy begins with search for a definition: what makes a state "small"? There is a vast number of definitions in the literature that emphasize one or another dimension. Pace $(2000,107)$ claims that despite of decades of study, no satisfactory definition has been found. Baehr (1975: 459) goes further arguing that due to definitional problems, the concept of smallness is useless as an analytical tool. According to him, definitions can be clear and unambiguous but arbitrary at the same time; more sophisticated definitions are also more ambiguous and difficult to apply to concrete cases. However, Hey $(2003,2)$ believes that no strict definition is necessary either to employ "smallness" as an analytical device or to glean findings about foreign policy behavior from it.

What is unanimous among the scholars is the conclusion that small states make up the vast majority of the international system. Of the 191 UN member-states it is estimated that no more than two dozen would assuredly fall outside this category (Neumann and Gstohl 2006, 3). The first wave of newly independent states during the 1960 's gave rise to a debate on how to define a small state; the second wave followed the collapse of socialist federations. The most common classification is based on an objective criteria, such as population, geographic area and economic capacity. (Crowards 2002, 143). Small states are also defined by their position within the international system. For instance, Vital (1971) argues that a small state is 'small' in relation to a greater power it is interacting with. According to Keohane (1969), small states are those that are "system ineffectual," that is they are unable to influence the international system.

The attribute of "smallness" has been indeed applied to so many different states, and not all of them are to be seen as vulnerable or insignificant in the international arena. The objective parameters do not always give a full picture of the position and role of a small state. For instance, one could hardly argue that Israel and Switzerland could easily fit in the category of small states; the same applies to Austria, Belgium, or even Luxembourg (all member-states of the EU). Advocates of the concept rather than a definition of small state emphasize that the concept of a small state is based on the idea of perceptions. A state is small if its people and institutions perceive it as a small, or if other states' peoples and institutions perceive it as a small. Perceptions matter - that is a bottom-line conclusion of scholars who stress that 


\section{Seccurity}

psychological dimension should go together with objective criterion by which to define smallness (Rothstein 1968, Keohane 1969). Small state usually recognizes that it cannot obtain security by its own capabilities, i.e. it have to rely on others. In the traditional academic thought, "small" in the context of foreign and security policy meant that such a state was perceived as no danger to neighboring states (Goetschel Laurent 1998,13$)$. That a state is deemed small not by any objective definition but by its perceived role in the international hierarchy, or even significance in preserving or imposing certain balance of power in the international system. The most recent case is Montenegro's joining NATO, and the interpretation that tiny state is not tiny anymore because of its impact on the US-Russia relations (Snider 2017). Due to the complexity of modern world, researchers are quite often left to follow the hunch "I know what is a small state when I see it", thus combining all relevant criteria in the current circumstances.

Small and/or weak states have always been enforced to invent foreign policy variations in order to survive and/or to protect their vital national interests. In 70-ties Vital (1971) elaborated that small states would rather seek out multilateral organizations and alliances to ensure their security and achieve foreign policy goals. He also believed that they would usually have limited foreign policy objectives and would engage in a relatively low number of international activities. Unlike him, East (1973) concluded that small states were more likely to get involved in international affairs, especially when the national stakes were high and high-risk action had become necessary. Katzenstein (1985) gave a different dimension to the issue by pointing out how the small European states outperformed their larger neighbors in policy flexibility and creativity in order to compensate for the lack of military and other capabilities.

In spite of the conventional truth that small size and weakness curtail foreign policy options and goals, many scholars also note that there are important exceptions to this rule. For instance, geography, importance to great powers, level development, internal stability, etc. are all factors that affect a small state's foreign policy behavior. Singer (1972) points out "attractive power" (importance to other countries) which small states could exploit in order to enhance their foreign policy success.

Research of small state foreign policy since the end of the Cold War displays two serious weaknesses: there are too few comparative empirical studies which impedes any serious theory building, and second - in the view of the dominant neorealist paradigm, small states are given subordinate status within political science, because 


\section{Seccurity}

the "big players" take the most scholarly attention due to their power to shape the international system (Hey 2003, 5). In sum, the available scholarly literature lacks a paradigm that may guide researchers to generate comparable and cumulative conclusions on small state foreign policy.

Having all this in mind, this case study has a limited ambition to examine foreign policy options and behavior of a specific Lilliputian state in South East Europe, not only in light of the changeable international system, but also with regard to the international state-building policies and internal instability.

\section{What Makes the Republic of Macedonia "Small" and/or "Weak"?}

The analytical framework for this research is the Rosenau's one (1966). The "father of comparative foreign policy" suggests a number of explanatory factors. According to him, foreign policy behavior vary according to three traits, such as: the size, the level of development, and the political system of a state. The factors are organized according to five levels of analysis: international system, role (bureaucratic actors), government (relationship among government actors), society (public opinion, national culture, etc.) and individual (state leadership). For purpose of this preliminary research we collapse role, government and society into one - state level. In spite of the new international environment, Rosenau's questions still ring true: to what degree are small states manipulated by the international system and the actions of the more powerful actors? In this article, we shall try to give answers to a set of questions concerning the Macedonian foreign policy behavior and options since 1991. At the system level analysis we shall focus on evidence about state security as an important factor in the state's foreign policy making and choices as well as to the influence of external (regional and global) actors and constellations. At the state level analysis, we shall seek evidence about domestic factors' influence on foreign policy. At the individual level we shall analyze leaders' decision-making authority and personal influence on foreign policy.

Smallness of the Republic of Macedonia is self-evident if one is to use objective parameters: the size of territory, population, GDP, natural resources, etc. What may not be visible at first sight is that Macedonia is not only a small country but she has been getting weaker since onset of its independence (Vankovska 2002; Krastev 2002). The 


\section{Seccurity}

independence came at the critical moment for the international system: bipolarity had just become past but expected peace dividend proved just a pipe-dream. The global transformation - where the old was gone but the new had not arrived yet - was ambiguous to say the least. On one hand, it offered chances for many newly established small states to gain independence, while on the other hand security risks had become very high due to the precarious collapse of multinational federations and interethnic upheaval. At first sight, it seemed that Macedonia's smallness and (military, political and economic) weakness did not interfere with its becoming a new international actor. Some scholars stick to this conclusion, pointing out that during Yugoslavia's collapse the small states such as Slovenia and Macedonia remained relatively safe and invulnerable in contrast to bigger states such as Croatia and Bosnia (Hey 2003, 8-9). This point of view, however, disregards Macedonia's vulnerability and the way she got UN membership. Under unprincipled pressure by Greece and then European Community, the new small state had to accept unprecedented conditions inflicted on her by the UN Security Council (i.e. great powers) with regard to its constitutional name (Janev 1999). As the years would soon prove, it was a turning point that made the Macedonian state not only small but also weak both in terms of international relations and domestic politics (Vankovska 2010).

State security has always been an important factor in foreign policy making and choices of the Republic of Macedonia. However, one should deconstruct the meaning of state security concept in order to understand Macedonia's concerns. For that purpose, we propose Bary Buzan's (2008) broader framework of security, and particularly the concept of societal security. For instance, Macedonia's insistence on joining NATO has much more to do with (national/ethnic) identity than with military or other security concerns. Naumovski (2013) is right arguing that the "name issue" has been a cornerstone of the Macedonian non-typical foreign policy: this paramount problem has been following the Macedonian state since the onset, i.e. seeking UN membership and international recognition in general. It contributed to disregarding all other diplomatic and foreign policy actions. Identity (of the Macedonian nation) has been also deeply embedded in the diplomatic relations with the neigbors.

According to Koneska (2014), the Macedonian foreign policy since 1991 has been focused onto two sets of objectives - one relating to the country's sovereignty and security, the other concerning its belonging to various international and regional organizations, in particular NATO and EU. One could also argue that it is hard to 
distinguish one objective from another for belonging to NATO and EU is seen as the ultimate way to achieve and secure the country's sovereignty and state security. Furthermore, NATO and EU are much more than usual foreign policy goals - they are tightly related to the internal state of affairs, including interethnic peace and stability. ${ }^{43}$ To make things worse, these international organizations are generally perceived in a non-dialectical way, as something static and ideal in spite of the crisis and dramatic changes of the constellations of the international relations. Official visits paid to any non-Western country have been a rarity in the Macedonian foreign policy. This situation has slightly changed with the VMRO-DPMNE led government (i.e. since 2006): due to economic reasons diplomats and political representatives have launched an "offensive" and "road-shows" all around the globe. The main goal has been an increase of direct foreign investments and other economic enterprises that would have a positive impact on economic growth. A part of the quest has been building closer ties with Russia in the energy sector through an inclusion in the South Stream gas pipeline to transport natural gas to Macedonia. ${ }^{44}$

The society deeply divided along ethnic/religious/language lines sees NATO (and EU for the same reason) as a glue to keep society together. However, the other identity problem related to the name issue (dispute with Greece, and indirectly with NATO and EU) prevents the country from reaching the goal, and intensifies further internal divisions. No wonder some Albanian politicians get often claim that "Albanians

${ }^{43}$ For two opposing views see: Bekim Nuhija, New Balkan Politics, 2013, no. 13, 142-153, available at: http://www.newbalkanpolitics.org.mk/item/The-impact-of-postponed-accession-of-Republicof-Macedonia-in-the-Euro-Atlantic-structures-to-the-inter-ethnic-relations\#.U7jsx5SSy3K. And: Biljana Vankovska, The EU integration as a security discourse: the curious case of the Republic of Macedonia, Heinrich Böll Stiftung magazine for south-eastern Europe - Agenda. 2011. no. 5, 57, available at: http://www.hr.boell.org/downloads/Agenda_5_Engl.pdf .

${ }^{44}$ South Stream is a project for construction a gas pipeline running under the Black Sea to Southern and Central Europe that has been carried by Russian company Gazprom. In July 2013 the Russian and Macedonian governments signed the Agreement of Cooperation in building a special branch for gas supplies to Macedonia. See: "South Stream construction to create conditions for developing gasification and gas-fired power generation in Macedonia". The South Stream project official website, 4 September 2013, available at: http://www.southstream.info/en/press/news/news-item/south-stream-construction-to-create-conditions-fordeveloping-gasification-and-gas-fired-power-gener/. 


\section{Securiagues}

[from Macedonia] will join NATO with or without the Macedonians". For many Macedonian citizens, membership in NATO and EU is a matter of survival of the state in face of internal insecurities. Macedonia has no confidence in her internal stability but she perceives lack of external certainty too. Thus foreign policy is mostly focused on state survival both from internal and external threats. Due to the inertia of the unipolar moment (i.e. domination of West, and particularly of the US in the region of former Yugoslavia), the state has accepted TINA principle - There Is No Alternative [to NATO, EU, close relationship and compliance to Washington and Brussels]. This course has not only limited foreign policy choices but also curtails any internal (expert or public) debate on foreign policy variations. Hence the emergence of the multipolar international system as well as the shadows of the Second Cold War has had no serious impact on Macedonia's foreign policy.

When it comes to state level analysis, the basic premise is that Macedonia is a rather autistic state (Maull 2017). The patterns of foreign policy behavior in the period 1991-2017 are persistently either too weak or too disruptive to realize the collective interests of that state and its people adequately and sustainably. Autism results also from the specific political dysfunctions or weaknesses as well as from the emotionally charged politics (be it with regard to the name issue and identity (for the Macedonians) or with fatalistic notion of belonging to NATO and EU as a matter of survival or ethnic unity (for the Albanians). It may also be seen as an expression of paralysis that results from excessive international involvement both in domestic and foreign policy tactics in policy- and decision-making.

Since 1991 it has been manifesting difficulties to react to and communicate with others. Having been a successor-state of an influential non-aligned state (Yugoslavia), it seems that Macedonia did not exploit any foreign policy experience or knowledge from the past (i.e. Non-Alignment Movement, NAM) ${ }^{45}$. Instead it has grown into a self-centered state, exclusively focused on (if not obsessed with) NATO and EU integration and almost unaware of any other global developments. The accession to NATO and the EU has strongly determined all foreign policy activities for more than 20 years. The only exception, or better a short 'excursion' into world politics, was the so-

\footnotetext{
${ }^{45}$ Currently, all former Yugoslav republics except Macedonia and Slovenia enjoy an observer status with the NAM.
} 


\section{Secururity}

called Taiwan episode (Tubilewicz 2004)..$^{46}$ On the Macedonian side the motivation was economic (and lucrative for a small group of politicians) but the effects were very harmful especially with regard to national security. If anything, the political elites learned that they had no capacity to play on an international scale without serious consequences, and that the great powers (such as China) should not be irritated.

The intensification of the international state-building efforts since the armed conflict of 2001 has led to another extreme - i.e. to a dependency syndrome both in domestic and foreign affairs. The so-called international community (mainly EU and US ambassadors and other officials) represent a third party in any internal stand-off. For instance, the EU mediators helped the political parties reconcile over the parliamentary crisis of 24 December 2012. Quite indicatively, among other issues, the so-called 1 March Agreement required "a Memorandum of Understanding affirming the cross-party consensus on, and commitment to, the country's strategic objective of EU and Atlantic integration" (Report from the Commission to the European Parliament and the Council 2013). Even it is true that there has been a long-term party consensus over NATO and EU, according to the Constitution the citizens will eventually have a final say on a national referendum.

Upon independence, understandably capacity building in the field of foreign policy was one of the greatest challenges for the Macedonian elites. However, it took 16 years to regulate the domain and to enact the first Law on Foreign Affairs. The statistics shows that Macedonia has established a vast network of consulates and embassies - far wider than it can financially and otherwise sustain. Foreign policy consensus (over NATO and EU membership) has been probably the only matter that brings different political and ethnic actors together. Yet as in other domains, partitocrazia (Siljanovska-Davkova 2016) has entered foreign policy to such a degree that diplomatic posts serve merely as rewards for obedient and not necessarily competent party soldiers. The foreign policy goals have not had priority in any of the coalition governments (usually made by a Macedonian and an Albanian political party). From institutional point of view, one should stress that foreign policy is almost

\footnotetext{
${ }^{46}$ In early 1999 the Macedonian government recognized the Republic of China (ROC) hoping that Taipei's generosity would resolve its economic problems. China, one of the first great powers that had recognized Macedonian independence after 1991, reacted in a predictable manner: Beijing suspended diplomatic ties with Skopje and vetoed the decision on extension of the UN preventive mission on the eve of NATO intervention in Kosovo.
} 


\section{Seccurity}

exclusive domain of the executive branch - i.e. government (foreign minister and the prime minister) and president of the Republic. According to some authors, the very fact that two bearers of executive power have foreign policy competencies gives the political system a semi-presidential form. Analysis of the constitutional arrangement yet shows that the government is a primary actor while the president in the parliamentary system has rather ceremonial and not a decisive role in foreign policy domain. In practice however Macedonia witnessed different influences depending on the charisma, experience and ambitions of the key-players.

The failure to get invitation for full NATO membership at the Bucharest Summit, have become a significant turning point both for the Macedonian internal and foreign policy. The national disillusionment has given the leading politicians free hand, which was mainly used for internal identity policy building and raising nationalism. The project known as Skopje 2014 is the best indicator for this dramatic change. Furthermore, the budgets of the Defense Ministry and Foreign Ministry have been downsized continuously. For instance, in the period 2010-2012 the latter's budget went down by $50 \%$ (Dokmanovic 2013, 57). Some domestic authors (llik 2013, 108) identify Eurodefetism in the public opinion, and even fear of 'change of the course' from EU to BRICS. Similarly, Koneska $(2014,103)$ speaks of recent dilution of the party consensus on foreign policy objectives due to the center-right VMRO-DPMNE (Internal Macedonian Revolutionary Organization - Democratic Party for Macedonian National Unity) increasing arguing against unconditional commitment to membership in NATO and EU if the country is enforced to compromise over the constitutional name in order to start accession negotiations. However, officially not a single political actor even less the government has ever developed a different path in foreign policy.

So far, the political elites have faced a tough choice between the Western allies only twice, and both times the decision was in favor of the US rather than the EU. The ratification of the bilateral agreement with the United States, granting US citizens' immunity from prosecution by the International Criminal Court (ICC) was the first instance of disregard of Brussels. The second example relates to Macedonia's decision to join the "Alliance of the Willing" in Iraq. Practically, Macedonia had placed herself among the states of so-called "new Europe". In both cases there was a shadow of doubt if the consent of the Macedonian leadership was voluntary; on the other hand, the public opinion was clearly against these two government's decisions. In general, the public opinion is quite impotent and irrelevant for any policy- or decision-making effort 


\section{Seccurity}

unless it concerns NATO and EU integration. The levels of public support are carefully measured and interpreted as all-national consensus. In a few cases when it dropped below 90 percent there was a slight sense of panic and a fear of (alleged) Euroscepticism. In other words, bottom-up popular input is of importance only with regard to a limited number of foreign policy issues.

Foreign policy approach offers a specific view, by breaking apart the monolithic view of a nation-state as unitary actor. The focus on the people and units that comprise the Macedonian state shed the light on divergences in terms of motives and values of the internal actors involved in foreign policy making. Under the surface of unity, the insightful analysis may differentiate certain variations depending on the actions undertaken by entities with mandate involving international affairs. The practice proves that despite the first impression, one could hardly speak of a coherent "Macedonian foreign policy". Furthermore, one could hardly speak of Macedonia's "national interest" due to the divergent interests of various internal players. Hence fragmentation dominates over consolidation of Macedonia's foreign policy. For instance, it has been a practice for ethnic leaders (be they politicians or intellectuals) to lobby and run a foreign policy of their own, regardless that general national interest. In the heart of the dispute is for instance the "name issue" that has substantially different meaning for ethnic Macedonians and ethnic Albanians living in the state. While the Macedonians hold hard line positions in terms of preservation of state name, the ethnic Albanians from Macedonia have overtly proposed accepting compromise in direct quasi-diplomatic offensives in Athens, Washington DC or Brussels.

At individual level, the starting premise is that although international system may constrain the activities of human actors, still human will may has major influence in sharping foreign policy of a state, or even world affairs (Hudson and Vore 1995, 210). This line of analysis is the best to be followed through the role of each president of the Republic in the foreign policy understanding and realization. For instance, the first Macedonian president Kiro Gligorov dominated both internal and foreign policy of the young state. He was an old and well-experienced politician with a much higher international profile than anybody else in the newly established elite. He was practically the only negotiator in most of the international affairs that the young state had to deal with. His authority had a strong impact on the understanding of the foreign policy and its realization. Koneska $(2014,102)$ argues that it was because of his traditional views on international politics that foreign policy was focused primarily on state security, 
while membership in international organizations was seen not as a normative imperative but rather as an instrument for protection of a small state's interests and existence. According to some analysts, things have changed since he left the position when the public discourse turned towards the narrative of Europeanization and values as a primary motivation for Macedonia's integration in the Western international organizations. Actually it was the internal conflict and post-conflict peace-building that welcomed the EU and NATO as mediator and state-builder with dominant influence on foreign policy rather than constitutional shift towards power-sharing model in 2001. At first sight president Trajkovski was not of a same caliber as Gligorov but it appeared that he had quite close relationship with the US administration. His political career skyrocketed in 1999 when he dared sharply respond to foreign journalists who attacked Macedonia's treatment of Kosovo refugees. Having been known as a "one statement man", Trajkovski became an obvious choice for the presidential candidate of VMRODPMNE in the coming elections. In 2001 he became a principled actor of the internal crisis due to the great international support he received. He allegedly authored socalled "Trajkovski's peace plan" although the public was aware that the idea had been internationally drafted and imposed. However, Trajkovski served as a spokesperson who actually announced and later on signed the Ohrid Framework Agreement. He was wellrespected as a man of peace and faith (due to his deep religious affiliation), and even more after his tragic death in a plane accident. From a rather marginal political figure with not much political and foreign experience, he grew up into a main player. It became clear when in December 2000 the public heard that Trajkovski obliged himself and wrote a letter of commitment to President W. Bush that Macedonia would support any Iraqi military intervention disregarding the Parliament and the Government which are constitutionally entitled to do so. The next president, Crvenkovski kept a low profile in the international relations and was merely focused on developing regional cooperation. The current president Ivanov has been marginalized both by the dominant Prime Minister Gruevski, and by the Western power centers, expect when he was needed to undertake unpleasant and 'dirty' jobs in the domestic politics and with regard to the migrant crisis. 


\section{Conclusion: Macedonia on the Frontline of Geopolitical Divisions}

The first foreign minister of independent Macedonia Denko Maleski (2013) argues that "in the third decade of our independence, Macedonia needs a new foreign policy". However, he not only fails to render what would be the newness of that foreign policy but there is not even a clear answer if Macedonia had ever had an old foreign policy (that should be abandoned). In our opinion the right and legitimate question reads: is a semi-protectorate (due to the excessive state-building building process run by the international actors) able to create and run a foreign policy according to its national interests? Or more precisely: does such a state need a foreign policy of its own at all? Based on the literature on power one should question if Macedonia is a 'small power', meaning that the state has weak military capability, or in Rothstein's terms, a state that recognize that it must rely on others for its security (Rothstein 1968, 29). The bizarre fact with Macedonia is that she is a weak state, both militarily and economically, but she has been seeking to exert influence over larger nations (primarily her neighbors, and European states) through strategic location and participation in military alliances (be they informal US-led coalitions or NATO endeavors). But intensive and relatively strong participation in Afghanistan and Iraq, a costly and hazardous venture, especially for a small country with limited resources, have not resulted in country's admission to NATO and EU. Involvement in peace and military operations stems from the belief of policy-makers that such activities promote the country's national interests by enhancing its influence in key international fora such as NATO or US-led operations. This is why researchers should focus on the perspective of dependency and vulnerability, not power. As far as Macedonia is concerned, one should keep in mind the slogan: the smaller the state, the less independent in reality. While claiming to be bearer of (nominal) independence, in the international arena Macedonia is nothing but a client of powerful states, even at expense of its national interests and/or the international norms and international law. On the other hand, Macedonia is an example of so-called autistic foreign policy, blind association with interests of external powers in hope she will eventually benefit from that, and complete inability to formulate and implement foreign policy choices due to the disastrous internal politics that make her an object rather than a subject in international arena. 


\section{BIBLIOGRAPHY}

1. Baehr, R. Peter (1975), "Small States: A Tool for Analysis?", World Politics, vol. 27, no. 3.

2. Buzan, Barry (2008), People, States and Fear: An Agenda for International Security Studies in the Post-Cold War Era. 2nd Edition, (Hertfordshire: Harvester Wheatsheaf).

3. Crowards, Tom (2002) "Defining the Category of 'Small' States," Journal of International Development, vol. 14, no. 2.

4. Dokmanovic Misho, "Оптимизација на мрежата на дипломатско-конзуларни претставништа во функција на надворешната политика - поуки за Македонија", in Political Thought. Special issue: Foreign policy and aspects of international diplomacy, vol. 11, no. 43.

5. East A. Maurice (1973), "Size and Foreign Policy Behavior: A Test of Two Models", World Politics, vol. 25, no. 4.

6. Goetschel, Laurent (ed.) (1998), Small States Inside and Outside the European Union: Interests and Policies, (NY: Springer).

7. Hey, Jeanne A. K. (ed.) (2003), Small States in World Politics, London: Lynne Rienner.

8. Hudson Valerie and Christopher Vore (1995), "Foreign Policy Analysis Yesterday, Today, and Tomorrow", Mershon International Studies Review, vol. 39, no. 2

9. Janev Igor (1999), "Legal Aspects of the Use of a Provisional Name for Macedonia in the United Nations System", American Journal of International Law, Vol. 93, No. 1.

10. Ilik, Goran (2013), "Normative power interrupted: the EU, BRICS and the Republic of Macedonia", New Balkan Politics, issue 14.

11. Katzenstein, J. Peter (1985), Small States in World Markets. Industrial Policy in Europe, Ithaca: Cornell University Press.

12. Keohane, Robert (1969), "Lilliputians' Dilemmas: Small States in International Politics," International Organization, vol. 23, no. 2. 


\section{Seccuriatity}

13. Koneska, Cvete (2014), "Policy consensus during institutional change: Macedonian Foreign Policy since Independence", in Keil Soeren and Bernhard Stahl (eds.), The Foreign Policies of Post-Yugoslav States. From Yugoslavia to Europe, (London: Palgrave).

14. Krastev Ivan (2002), "The Balkans: Democracy without Choices", Journal of Democracy, vol. 13, no. 3.

15. Maleski Denko (2013), "On nationalism, identity and the foreign policy of Macedonia", New Balkan Politics, no. 14.

16. Maull, Hans (2017), "Autism in Foreign Policy", Stiftung Wissenschaft und Politik (SWP) Digital Library, Zurich, available at: http://www.css.ethz.ch/en/services/digitallibrary/articles/article.html/92d62436-ee79-4257-973b-0c9bdf77b57c/pdf.

17. Naumovski Vasko (2013), "Десет препораки за македонската надворешна политика во третата деценија од независноста", in Political Thought. Special issue: Foreign policy and aspects of international diplomacy, vol. 11, no. 43.

18. Neumann Iver B. and Sieglinde Gstohl (2006), "Introduction: Lilliputians in Gulliver's World?" in Christine Ingebritsen et al. (eds.) Small States in International Relations, (Seattle: University of Washington Press).

19. Pace Roderick (2000), "Small States and the Internal Balance of the European Union: The Perspective of Small States" in Cower Jackie and John Redmond (eds.), Enlarging the European Union: The Way Forward, (NY and London: Ashgate).

20. REPORT FROM THE COMMISSION TO THE EUROPEAN PARLIAMENT AND THE COUNCIL, 16.4.2013, Strasbourg, available at:

http://ec.europa.eu/enlargement/pdf/key_documents/2013/mk_spring_report _2013_en.pdf

21. Rosenau, N. James (1966), "Pre-theories and theories of foreign policy", in R. Barry Farrel (ed.), Approaches in Comparative and International Politics, (Evanston: Northwestern University Press).

22. Rothstein, Robert L. (1968), Alliances and Small Powers, (New York: Columbia University Press).

23. Siljanovska-Davkova, Gordana (2016), "Two Faces of Internal Life of Political Parties in Western Balkans", Revista Ballot, Rio de Janeiro, vol. 2, no. 1, available at: http://bibliotecadigital.tse.jus.br/xmlui/handle/bdtse/2689 
24. Singer Marshall (1972), Weak States in a World of Powers: The Dynamics of International Relationships, (NY: Free Press).

25. Snider Ted (2017), "Trump, Russia, and NATO: Why Tiny Montenegro's Not Tiny Now", Antiwar, April 15, available at: http://original.antiwar.com/Ted_Snider/2017/04/14/trump-russia-and-natowhy-tiny-montenegros-not-tiny-now/ (accessed on 17 April 2017)

26. Tubilewicz, Czeslaw (2004), "Taiwan's 'Macedonian Project' 1999-2001", The China Quarterly, 2004, vol. 179. Available at: http://digital.library.adelaide.edu.au/dspace/bitstream/2440/46919/1/Tubilew icz.pdf (accessed on 26 April 2017)

27. Vankovska Biljana (2002), Current Perspectives on Macedonia. Part I: The Path from "Oasis of Peace" to "Powder Keg" of the Balkans. Henrich Böll Foundation.

28. Vankovska Biljana (2010), 1."David vs. Goliath: Macedonia"s Position(s) in the 'Name Dispute' with Greece", Sudosteuropa, vol. 58, no. 3.

29. Vital, David (1971), The Survival of Small States (London: Oxford University Press).

30. Scheldrup, Macklin (2014), "Lilliputian Choice: Explaining Small State Foreign Policy Variation", 